\title{
The role of the airbus A380-800 aircraft in a full- service network airline's commercial operations and route network design: the case of Thai airways international
}

\begin{abstract}
Aircraft fleet deployment and route network design are two of the most critical elements of an airline's business model. Using an in-depth exploratory case study research design, this study examined the role of the Airbus A380-800 aircraft in Thai Airways International commercial operations and route network design during the $2017 / 2018$ winter flight schedule period. The qualitative data was examined by document analysis. Thai have deployed their Airbus A380-800 aircraft on routes from Bangkok to Frankfurt, Osaka's Kansai International Airport, London and Paris and return. The services are targeted at both the premium (first/business) and leisure travel market segments. The Airbus A380 services from Bangkok to London will produce the greatest number of ASKs (1.42 billion), AFTKs (45.1 million) and ATKs (195.0 million). This is followed by Paris with 1.41 billion ASKs, 44.4 million AFTKs and 192.4 million ATKs. Frankfurt is the third largest market with 1.34 billion ASKs, 42.3 million AFTKs and 183.2 million ATKs. The daily Airbus A380-800 services between Bangkok and Kansai International during the 2017/2018 winter flight schedule period will produce 620.2 million ASKs, 19.5 million AFTKs and 84.6 million ATKs. The European services generate 87 per cent of the Airbus A380-800 fleet's available seat kilometres (ASKs), available freight tonne kilometres (AFTKs) and available tonne kilometres (ATKs).
\end{abstract}

Keywords: airlines, air cargo, Airbus A380, available seat kilometres, available freight tonne kilometres, case study, fleet deployment, route network design, Thai airways international
Volume 2 Issue 4 - 2018

\author{
Glenn Baxter,' Panarat Srisaeng,' Graham \\ Wild ${ }^{2}$ \\ 'Suan Dusit University, Thailand \\ ${ }^{2}$ School of Engineering, RMIT University, Australia
}

\begin{abstract}
Correspondence: Graham Wild, Post Graduate Program Manager and Senior Lecturer,Aviation, School of Engineering, RMIT University, I 24 La Trobe Street, Melbourne VIC 3000, Australia,Tel +6I 3992 5805I,

Email Graham.Wild@rmit.edu.au
\end{abstract}

Received: June 06, 2018 | Published: July 30, 2018

\section{Introduction}

The global air transport industry plays a fundamental role in facilitating economic growth, this is especially so in developing countries, tourism, commerce and linking countries and regions. ${ }^{1}$ Air transportation is defined as the transportation of persons, goods, property or postal mail by air. It comprises two primary segments, the transport of passengers as well as the carriage of air cargo consignments. Each segment of the industry has its own unique characteristics, yet the two are difficult to consider in isolation, therefore air transportation is often referred to as a "bi-polar" industry. ${ }^{2}$ In 2016, the world's airlines carried around 3.79 billion passengers and 52.6 million tonnes of air cargo. ${ }^{3}$ Furthermore, the air transport industry is regarded as being indispensable for tourism, ${ }^{4}$ which is also a strong driver of economic growth..$^{5-7}$ In 2016, around 55 per cent of all overnight visitors travelled to their destination by air. ${ }^{4}$ In the global airline industry, passenger airlines have defined and implemented two principal business models: the full-service network carrier (FSNC) and the low-cost carrier (LCC) models. ${ }^{8}{ }^{8}$ Whyte \& Lohmann ${ }^{10}$ note that a 'business model is a conceptual structure or plan that defines how a company conducts its business'. The full-service network carrier's business model forms the focus of the present study.

Airline route networks and fleet composition and deployment are viewed as being two of the most critical elements of an airline's business model. FSNCs target large passenger and air cargo traffic catchment areas, while, simultaneously, bundling traffic from smaller, peripheral traffic catchment areas into their hub airport. This strategy is designed to enable them to operate profitable intercontinental air services. ${ }^{11}$ The major airlines typically structure their route networks based on the hub-and-spoke principle whereby they link together smaller peripheral markets via their major hub airports. This strategy enables them to optimise both passenger and air cargo connectivity. In addition, many of the world's airlines structure their route networks on short haul, medium-haul, and long-haul services. ${ }^{12}$ Airlines sell passenger kilometres but produce seat kilometre. Thus, like revenue passenger kilometres, available seat kilometres (ASKs) reflect the spatial nature of their output. ${ }^{13}$ Available seat kilometres (ASKs) is the total number of seats offered on a flight multiplied by the stage length flown. ASKs are commonly used as a key measure of air transport passenger capacity in the global airline industry ${ }^{14,15}$ and are another measure of aircraft productivity. ${ }^{16}$ Freight tonne kilometres are a measure of an airline's air cargo traffic. ${ }^{17}$ Available freight tonne kilometres represent one tonne of air cargo carried one kilometres. ${ }^{18}$ Tonne kilometres performed (TKP) is a measure of the tonnes available for the transportation of passengers, air cargo and postal mail, times the distance flown by the aircraft. ${ }^{18,19}$ TKPs may be measured for a single flight, for an entire airline or for the industry. ${ }^{18}$

The concept of the 'super jumbo' or very large aircraft (VLA) was conceived in the mid-1980s, when the two major aircraft manufacturers-Airbus SAS and Boeing Commercial Airplanes-both 
contemplated the requirement for a very large passenger aircraft. Airbus embraced a philosophy of designing and building an aircraft that could large numbers of passengers between hub airports. Airbus envisaged a double-deck aircraft that could carry 550 passengers when deployed in a three-class cabin configuration or up to 850 passengers should an operator have such requirement. ${ }^{20}$ The Airbus A380 entered commercial service on October 25, 2007 when it operated Singapore Airlines flight SQ380 from Singapore to Sydney. ${ }^{21,22}$ At the time of the current study, there are 222 Airbus A380 aircraft in operation, and Airbus SAS has an A380 backlog of 95 aircraft. ${ }^{23}$

The objective of this study is to examine the Airbus A380-800 fleet deployment in the 2017/2018 winter flight schedule period by Thai Airways International, a major global full-service network carrier. The period of the study was the winter flight schedule period, which commences on October 29, 2017 and concludes on March 24, 2018. The study also aims to examine the types of markets, that is, leisure or business markets that these aircraft are being deployed in by Thai Airways International. An additional aim is to determine the total available seat kilometres (ASKs), available freight tonne kilometres (AFTKs) and total available tonne kilometres (ATKs) for each city pair that are operated by the Airbus A380 aircraft. A final aim of the study is to assess the daily block hours flown by Thai Airways International fleet of Airbus A380-800 aircraft. The remainder of the paper is organized as follows: the literature review presented in Section 2 commences with a brief overview of the full-service network carrier's business model, airline aircraft fleet mix and deployment, aircraft cabin configurations, airline route network design, the provision of belly-hold cargo transportation, and a review of the Airbus A380-800 aircraft. The research method that underpinned the study is described in Section 3. The empirical examination of Thai International Airways Airbus A380-800 aircraft deployment is presented in Section 4. The key findings of the study are described in Section 5.

\section{Background}

\section{The key elements of the full-service network carrier business model}

A "full service network carrier" (FSNC) or "legacy" carrier is an airline that focuses on providing a broad range of both pre-flight and onboard services, including different cabin classes, and connecting flights. Since most FSNCs operate a hub-and-spoke route network model, this group of airlines is quite often referred to as hub-and-spoke carriers. ${ }^{24}$ British Airways, Cathay Pacific Airways, Emirates Airline, Etihad Airways, Qantas, Singapore Airlines, Thai International Airways and United Airlines are examples of full service network carriers (FSNCs). FSNCs normally focus on the same operational, strategic and economic features: that is, they define and operate a complex network of air services. Under this strategy they combine many smaller regional services with intercontinental services using a hub-and-spoke route system. This is normally accompanied by a product/service strategy that is underpinned by discrete travel class differentiation, and by offering a full range of services to all passengers, regardless of their class of travel. ${ }^{11}$ Route network and the aircraft fleet type employed are two of the major elements defining the FSNC business model. FSNCs target large traffic catchment areas, while, simultaneously, bundling traffic from smaller catchment areas into their hub airports. This enables them to operate profitable intercontinental air services. ${ }^{11}$

\section{Aircraft fleet mix and deployment}

An airline's "fleet" is the total number of aircraft it operates at a given time. The aircraft fleet is also comprised of the specific aircraft types that are operated by the airline.$^{25}$ Each aircraft type has different technical performance characteristics, for example, their ability to operate services on short haul thin air routes or alternatively operate long haul major intercontinental routes. ${ }^{26} \quad$ While several aircraft may be considered capable of serving a route, certain aircraft will be better matched to those unique market conditions, be it time of day, day of week, and so forth. A fleet that comprises aircraft that can serve all market needs effectively and efficiently should place that airline in a strong financial position. ${ }^{27}$ Since the FSNC route network is often designed to link regional, continental and intercontinental routes, the typical FSNC fleet is usually quite heterogeneous in nature. An FSNC aircraft fleet may comprise small regional jets right through to long range wide-body aircraft, such as the Airbus A380. The diversity in aircraft types operated is because FSNCs endeavor to have the right aircraft in place for each route alone. This results in a broad range of available seating capacities. In the airline industry, many airlines pursue a multiple aircraft manufacturer strategy, that is, the purchase and/or lease aircraft both Airbus and Boeing aircraft. Accordingly, flight and cabin crew, technical staff, spare parts, ground handling equipment and staff and other production factors need to be provided for entirely different aircraft types, therefore adding to the airline's cost base. ${ }^{25,26}$

Commercial aircraft are commonly defined by their range and size. The range being the maximum distance it can fly with a full (or reasonable) payload of passengers and air cargo, while its size is represented by its weight and capacity (seats and cargo). ${ }^{25,26}$ Broad categories like short-haul, long-haul and ultra-long-haul are used by aircraft manufacturers. Aircraft with similar characteristics are then more easily compared with the competitor's product offerings. ${ }^{26}$ There are two fundamental reasons for airlines acquiring aircraft. Firstly, airlines acquire aircraft to replace existing capacity. In replacing existing capacity, the task for the airline is to find an aircraft that can perform a largely unchanged mission better than those aircraft that are being replaced. ${ }^{18,28}$ An airline might find it necessary to replace part of its existing fleet due to high operating costs, unacceptable aircraft noise or emissions, limited remaining aircraft structural life, inadequate passenger appeal, fleet rationalization, or because of an ongoing fleet rollover policy that is intended to maintain a young fleet age. Normally the task for an airline is to find an aircraft that it deems capable of performing a largely unchanged mission more effectively than the aircraft to be replaced. ${ }^{18}$ The second reason why airlines acquire new aircraft is to grow their existing capacity. The growth in total capacity often interacts with the requirement for aircraft replacement and is further complicated by the fact that growing passenger (and air cargo) demand can in principle, be satisfied by using larger aircraft and maintaining flight frequencies. This can be achieved by operating the same size aircraft at higher frequencies (possibly optimizing additional utilization and/or higher load factors out of the existing fleet before adding further capacity), or by some combination of the two..$^{29}$

On an airline route-by-route basis, it is normally true that additional frequencies have historically accounted for a significantly higher percentage of additional airline output supplied to satisfy demand growth than have larger aircraft. In addition, capacity might 
have to be added to satisfy a new mission requirement-for example, a hub-bypass by operating point-to-point (P2P) services. ${ }^{29}$ Furthermore, additional capacity may be required by an airline to satisfy new mission requirements that are beyond the capability of the airline's existing fleet, such as the operation of ultra-long-haul services. ${ }^{18}$ Aircraft fleet assignment or deployment is the tactical decision made by the airline once the initial flight schedule has been produced and generally takes place a long time after the decisions about fleet acquisition and route network have been made. The primary aim of fleet deployment by an airline is to minimize the combined costs of 'spill' or rejected passenger demand and aircraft operating costs. ${ }^{16}$ The other important objective of fleet deployment is to assign as many flights as possible in a flight schedule to one or more aircraft types, whilst also optimizing some objective function and satisfying various operational constraints. Fleet deployment therefore involves the airline matching each aircraft type in its fleet with a specific route in the flight schedule. ${ }^{30}$ Fleet deployment or assignment is off course restricted to a choice of the aircraft types from the airline's aircraft fleet mix. ${ }^{26}$

\section{Aircraft cabin configuration and passenger comfort}

The requirement for product innovation by airlines in the global airline industry has certainly intensified. Since flight schedules, in most cases, can be changed only in the medium term, if at all, airline product development has often concentrated on improving comfortbased features of the airline's product and service offering. In fact, these can be changed by the airline more readily and quite quickly. These aspects of the airline product service offering are viewed as being highly important by passengers when determining their perceptions of the level of comfort provided by the airline that they may desire to use for their travel plans. ${ }^{17}$ The first comfort-based airline product feature is the aircraft interior layout and configuration, which influences the width and pitch of each seat, and thereby, determines the amount space that is available to each passenger. ${ }^{31}$ Individual space in the aircraft appears to be the key comfort variable for passengers, but so too is the quality of the seating provided by the airline. Comfort is regarded as very important for passengers flying on long-haul intercontinental services, as well as for those flying on business and those travelling on leisure/holiday trips. But, most importantly, there is a trade-off between the aircraft seating density and the airline's unit costs. This is because the more seats that can be accommodated in the aircraft the lower the operating costs per seat. Consequently, the decision by airlines as to the seating density on their aircraft will have major cost implications for the company. ${ }^{17}$

A key aspect of passenger-related comfort relates to the width and pitch of the airline seat. Pitch is the distance between two seats ${ }^{32}$ and is a measure of the leg-room that is available to passengers. ${ }^{17}$ Typically, aircraft seat width varies from 17 inches (tight) to 22 inches (good comfort) and is designed to satisfy the 16-g government impact regulations. Flexibility is built into the aircraft design by the aircraft manufacturers to enable airlines to adopt the seating arrangement in accordance with market requirements. ${ }^{32}$ In recent times, many airlines have introduced sleeping accommodation (flat-bed seats) in larger aircraft. Such an arrangement is normally used for long-haul flights. ${ }^{33,34}$ The installation of flat-bed seats is generally achieved by rearranging aircraft cabin space. ${ }^{17,32}$ Other key aspects of the aircraft interior layout which an airline must decide upon, since they influence the nature of the product/service offering it is offering, include the number of separate classes of cabin and service, the number of toilets to be installed in their aircraft, the types of seats installed, interior aircraft design and cabin colour schemes, and the size as well as the suitability of overhead lockers. ${ }^{17}$ An airline that is seeking to attract business or premium class passengers will most probably have more than a single class of service. Typically, only three classes of service (first, business and economy) are normally only viable on long-haul dense intercontinental or trans-continental air routes..$^{35}$

\section{Airline route network design}

As previously noted, the FSNC business model is generally based upon the operations of a hub-and-spoke route network. ${ }^{10,12}$ In the FSNC hub-and-spoke system, airlines develop their networks by combining features from non-stop and multi-stop routing patterns. The hub operational system is based on flights arriving from multiple points (spokes) at a hub airport where passengers, baggage and air cargo connect to flights departing to multiple points. So, after a short turnaround period, an equally substantial number of turn-around departures travels out along spoke routes from the hub. The hub airport thereby acts as a gathering and consolidation point for flights operating to multiple destinations. ${ }^{35,36}$ The hub-and-spoke system, by offering a wide variety of origins-and-destinations (O \& Ds) or city pairs, therefore, assists airlines to exploit other economies of market presence. Combining substantial volumes of domestic traffic with international traffic through hubs further enhances this advantage. ${ }^{37}$ The hub-and-spoke strategy of FSNCs leads to a focus on primary airports, being those airports, which belong to a highly populated urban area/region or business centre, and typically serving more than several million passengers per annum. While these airports guarantee sufficient passenger traffic to fill the number of flights necessary for an airline to efficiently operate the hub, and hence, provide the infrastructure required to cope with the peaks resulting from hub operations, this strategic focus often results in disadvantages for airlines when it comes to punctuality. Primary airports, being a preferred destination for all types of airlines, tend to suffer from congestion and generate flight delays and operational bottlenecks. ${ }^{11}$

Hub operations are amongst the most valuable assets that a FSNC owns. They enable an airline to operate routes which could never be profitably served by local traffic alone. In total they form the economic basis for a network density typically exceeding a point-topoint coverage by a substantial amount. ${ }^{11}$ Accordingly, the hub-andspoke system encourages airline growth. By using hub-and-spoke operational systems, airlines can increase traffic density on certain routes, thereby taking advantage of economies of traffic density, and lowering unit costs. The benefits also arise on the demand side, as passengers prefer to travel with larger airlines, so an airline with an extensive hub and spoke system possesses an advantage over a new entrant and smaller airlines due to the larger network of points served. ${ }^{19}$ As the numbers of passengers expands on in an origin and destination market $(\mathrm{O} \& \mathrm{D})$, it becomes economically feasible for airlines to deploy larger aircraft types and/or provide more frequent services. Furthermore, in the airline industry, there are often "thin" routes, that is, routes that have a small number of passengers per day, and "dense" routes, where there are significant numbers of passengers travelling each day. Typically, dense air routes are served by pointto-point service, whilst thin routes are combined using the hub-andspoke system..$^{38}$ Economies of traffic density are especially important aspect of airline economics. On per seat or per kilometer basis, the costs are lower for larger aircraft. Consequently, the costs per seat and cost per tonne kilometer are low on long-haul large aircraft types, 
such as, the Airbus A380-800. In contrast, they are high for smaller aircraft, such as regional jets. As a result, on 'dense' or very busy routes, which can better sustain larger aircraft types, there will be lower air fares than those on low density or 'thin' routes. Moreover, denser air travel routes will have more services, which will be more convenient for the airline's passengers. ${ }^{39}$

\section{Airline travel market segmentation}

According to Wensveen ${ }^{28}$ airline market segmentation is the process whereby an airline divides potential customers for one of its products or services into a meaningful consumer group, or market segments. Shaw ${ }^{40}$ further notes that 'a market segment comprises a group of customers who have sufficient in common that they form a viable basis for a product/price/promotion combination'. In the world airline industry, market segmentation is a customary practice principally aimed at separating business-oriented travel from leisureoriented travel. Hence, airlines have historically segmented passengers into two distinct categories based on the reason or purpose for travel: business and leisure. ${ }^{25,41,42}$ Below this level, business travelers may be travelling to attend conferences, or a marketing or travelling on a reward program incentive (Figure 1). Leisure travelers may be travelling on holidays, or for study purposes, or visiting friends and relatives (VFRs) (Figure 1). Importantly, there are some markets that principally attract business travelers, whilst there are other markets that are dominated by leisure travelers. ${ }^{42}$

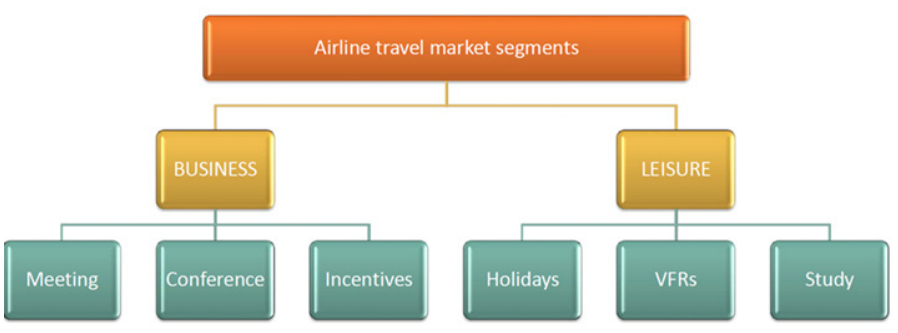

Figure I Airline passenger air travel market segments.

The transportation of air cargo in passenger aircraft lower deck belly holds

In the air cargo industry, slightly under half of world air cargo traffic is carried in the lower deck belly holds of passenger aircraft. ${ }^{43}$ This arrangement, in which passengers are carried on the aircraft's main deck, and air cargo is carried below in the lower deck belly hold compartments, is referred to as a combination aircraft. ${ }^{2,42,44}$ Importantly, the design of passenger aircraft is dictated by passenger requirements, space for air cargo transportation is what is left over in the otherwise unusable space below the main passenger deck of the aircraft that is not required for the stowage of passengers' luggage and that exists simply due to the aerodynamic requirements for a tubular shape for the aircraft fuselage. ${ }^{45}$ The introduction of wide-bodied passenger aircraft, such as the Boeing B747 in the 1970s resulted in a substantial increase in space available to carry cargo in the lower deck or belly-hold compartments. Combination airlines air cargo capacity may come in the form of narrow bodied, single-aisle aircraft, such as, the Airbus A320 or Boeing B737NG aircraft, or wide-bodied, twin aisle aircraft, such as the Boeing B787-9 aircraft. Other wide-bodied aircraft include the Airbus A350-900XWB, Boeing 777-300ER and 747-8 aircraft as well as the Airbus A330 and A380 aircraft.

\section{Airbus A380-800: a brief overview}

The origins of the Airbus A380 aircraft date back to 1988, when the first interest in the Airbus ultra-high capacity aircraft first occurred. The A3XX integration team was formed in October 1993 and this was subsequently followed in 1996 with the establishment of the Large Aircraft Division. ${ }^{46}$ During 2000, Airbus has accumulated sufficient customers to launch its double-decker A3XX program. ${ }^{47}$ The Airbus A380 program was formally launched on 19 December $2000 .^{48}$ The Airbus A380 was designed to on both existing and probable future high-density routes that were predominantly operated by the Boeing B747-400. These routes included Bangkok, Hong Kong, Singapore, Tokyo to Europe and the United States. ${ }^{49}$ The first flight of the Airbus A380 took place on the 27th April 2005. ${ }^{50}$ There are a number of structures on the Airbus A380 that use textile composite materials. These include the six metre dome- shape pressure bulk head and the wing trailing edge panels. Both have been produced using resin film infusion (RFI) with carbon non-crimp fabrics, wing stiffeners and spar made by RTM. The aircraft's vertical tail spar is made by vacuum infusion (VI), and thermos-plastic composite (glass/phenylene sulphide) has been used for the leading edges of the aircraft's wings. ${ }^{51}$ The Airbus A380 is the biggest passenger aircraft ever built ${ }^{52,53}$ and was the world's first double-deck passenger aircraft. On October 15, 2007 the first AirbusA380-800 aircraft was delivered to Singapore Airlines. ${ }^{54}$ Singapore airlines commenced Airbus A380 commercial operations on 25 October 2007, when it commenced daily Airbus A380 flights between Singapore and Sydney. ${ }^{55-57}$ There are two engine families offered for the Airbus A380. These are the Engine Alliance GP7200 series and the Rolls Royce Trent 900 series engines. The Airbus A380-841 comes equipped with the Rolls Royce Trent 970 engines, whilst the A380-861 has the Engine Alliance GP7270 engines..$^{58}$ The aircraft has a maximum range of 15,200 kilometres and a maximum take-off weight of 575 tonnes.

\section{Research method}

The research undertaken in this study was exploratory in nature ${ }^{59,60}$ and followed an inductive approach using a qualitative research method. ${ }^{61,62}$ The goal of such an approach is to expand and build theories rather than perform statistical analysis to test a certain hypothesis. ${ }^{51}$ As Yin $^{63}$ notes, a case study, whilst like an experiment, does not represent a sample, and the researcher's role is to expand and generalize theories (analytical generalization) and not to enumerate frequencies (statistical generalization). Data for the study was obtained from a range of documents, company materials available on the internet and records as sources of case evidence. Documents included the Thai Airways International flight schedules, annual reports, press releases, and the airline's websites. The study therefore used secondary data. The three principles of data collection as suggested by $\mathrm{Yin}^{60}$ were followed: the use of multiple sources of case evidence, creation of a database on the subject and the establishment of a chain of evidence.

The empirical data collected for the case studies was examined using document analysis. Case studies often use document analysis. ${ }^{64-66}$ Document analysis focuses on the information and data from formal documents and company records collected in the study. ${ }^{60,67} \mathrm{Scott}^{68}$ and Scott \& Marshall ${ }^{69}$ suggests that there are four criteria that can be taken into consideration when assessing the quality of historical documents: authenticity, credibility, representativeness and meaning. Prior to conducting the formal analysis of the documents gathered in the study, 
the context in which the documents were created was determined and the authenticity of the documents was assessed. ${ }^{70}$ According to Chester, ${ }^{71}$ authenticity refers to whether a document is genuine, complete, and reliable as well as being of unquestioned authorship. Authenticity also addresses whether their production is original, are not of questionable origin, and that they have not been subsequently altered. If a document has been found to be transformed, through textual editing, marginalia, or any other means, then the researcher is required to clearly identify those alterations..$^{72}$ This criterion can largely be applied in assessing the value of historical material. ${ }^{15}$ Once it has been determined by the researcher that the document is "genuine and of unquestionable origin," then the material can be considered "valid" as an artifact. However, the document's content may still be questionable or subsequently found to be "incorrect" at a later stage. ${ }^{72}$

Whilst any form of qualitative data may be original and genuine, that is, authentic, it is possible that the content may still be distorted in some manner. Thus, a second criterion in appraising materials is determining their credibility and identifying whether the document's information is both honest and accurate..$^{72}$ Hence, credibility refers to the extent to which a document is sincere and not distorted and is free from error and evasion. ${ }^{68}$ In assessing this criterion, it is necessary for the researcher to determine whether the document can be regarded as a credible, worthwhile piece of evidence and, also in some instances, whether it is accurate. ${ }^{73} \mathrm{~A}$ third criterion, representativeness, refers to the "general problem of assessing the typicality or otherwise of the evidence" $" 74$ collected for the study. A document's representativeness may become distorted over time. This is because with the passing of time the survival rate of certain materials becomes greater as the items may have been viewed as less valuable. Accordingly, the document(s) may have been stored away, rarely viewed following their point of origination, and hence, preserved. Furthermore, some important documents do not survive because their great significance caused them to become well used and worn. Consequently, they may be discarded while on the other hand less important documents survive because they attract so little use. ${ }^{74}$

A final criterion-meaning-refers to the degree to which the evidence is clear and comprehensible to the researcher(s $)^{72,74}$ and concerns the assessment of the actual documents gathered for the study ${ }^{73} \mathrm{Kridel}^{72}$ notes that "coupled with this semiotic and intertextual examination is whether the document's content is appropriately situated within its historical context; this is ascertained, in part, by the method in which meaning is constructed and perceived by its originally intended audience". The four criteria-authenticity, credibility, representativeness and meaning-should not be regarded as separate and discrete stages when assessing documents. Rather, they are interdependent, and thus, a researcher cannot adequately consider one without simultaneously considering the others. ${ }^{75}$ Hence, in this context, the assessment of documents is an ongoing, neverending process. Scott ${ }^{75}$ notes that "the interpretive meaning that the researcher aims to produce is a tentative and provisional judgment that must be constantly revised as new discoveries and new problems force a re-appraisal of the evidence". Most importantly, Scott ${ }^{75}$ states that "an understanding of this is essential if a researcher is to make sensible use of documents".

Documents are one of the principal forms of data sources for the interpretation and analysis in case study research. ${ }^{76}$ When conducting document analysis, the related analysis and assessment of documents occurs as materials are ascertained as being in the public or private domains as well as whether the documents are primary or secondary (noting that a primary source need not be the sole original document; primary materials are first-hand documents). Another important aspect of document analysis is whether the researcher(s) have directproximate contact (that is, being able to examine the original or primary document) or indirect-mediate access, for example, a scanned electronic-version. ${ }^{72}$

The document analysis was undertaken in six distinct phases as follows:

a. Phase 1: This phase involved planning the types and required documentation and their availability.

b. Phase 2: The data collection involved gathering the documents and developing and implementing a scheme for the document management.

c. Phase 3: Documents were reviewed to assess their authenticity, credibility and to identify any potential bias.

d. Phase 4: The content of the collected documents was interrogated, and the key themes, data and issues were identified.

e. Phase 5: This phase involved the reflection and refinement to identify and difficulties associated with the documents, reviewing sources, as well as exploring the documents content.

f. Phase 6: The analysis of the data was completed in this final phase of the study. ${ }^{77}$

\section{Case study}

\section{A brief overview of Thai Airways International}

The origins of Thai Airways International date back to November $1^{\text {st }}, 1951$ at which time Thai Airways Company Ltd was formed. This followed the merger between Siamese Airways Company Limited and Pacific Overseas Airlines (Siam) Limited. Following the merger between the two airlines, the Thai Airways Company operated both domestic and international services to Hong Kong, Tokyo and to some other destinations. On 24 August 1959, Scandinavian Airlines System (SAS) signed an agreement on 24 August 1959 under which Thai Airways International was formed. The new airline assumed the international routes that were previously operated by Thai Airways. ${ }^{78}$ Thai Airways International (THAI) held 70 per cent of the issued shares whilst SAS held the remaining 30 per cent of the company's shares..$^{79}$ On 1 November 1964, Hawker-Siddeley 748 services began to supplement the airline's fleet of Douglas DC-3 aircraft. The company operated flights to Vientiane (Laos) and to Penang in Malaysia. It also operated an extensive domestic route network. ${ }^{78}$ During this time, SAS provided operational support, crew and aircraft. ${ }^{80}$

The company's route network expansion continued and on 1 May $1960^{6}$ it commenced services from Bangkok to Calcutta and from Bangkok to Singapore. These services were operated by a small fleet of three Douglas DC-6B aircraft that had been leased from SAS. Route expansion occurred quite quickly and 'Royal Orchid' services were introduced to Kuala Lumpur, Singapore, Jakarta, Calcutta, Saigon, Hong Kong, Taipei and Tokyo. ${ }^{80}$ During 19621963, two Convair 990A aircraft were leased from SAS, but these were subsequently replaced by SUD Aviation Caravelles. The first of 5 SUD Aviation Caravelles leased from SAS entered commercial service with Thai International Airways in January 1964. In 1970, 
two McDonnell Douglas DC9-40 aircraft were acquired, and in 1971, two additional McDonnell Douglas DC8-62 and four DC8-30 aircraft had also entered commercial service. During the early 1970s, Thai Airways International continued to expand its route network with the introduction of services to Manila, Osaka, Dacca, Kathmandu, Delhi and Denpasar, Bali. In April 1971, Thai Airways International commenced services to Australia with a flight operated to Sydney. This service was operated via Singapore. In June 1972, the airline commenced services to Europe, with the introduction of services from Bangkok to Copenhagen and London. ${ }^{78}$ In April 1980, the airline started services from Bangkok to the USA. ${ }^{81}$

In March 1977, SAS sold its share to the Thai government in March 1977. Following this share acquisition, the government had overall control of the airline. Currently, Thai Airways International Public Co, Ltd is a national enterprise that falls under the auspices of the Ministry of Transport. Also, since 1991, the airline has been a public company that is registered with The Securities Exchange of Thailand. The Ministry of Finance is the largest shareholder in the airline, holding more than 50 per cent of the company's shares. ${ }^{82}$ Thai Airways International has defined and implemented the full-service network carrier business model. The airline operates a hub-and-spoke route network from its principal hub at Bangkok's Suvarnabhumi International Airport to Australasia, Europe, the Middle East, Indian Sub-continent and to South and North-East Asia. The airline also operates domestic services to key tourism markets in Thailand. Figure 2 shows THAI's total annual revenue passenger kilometres (RPKs) and freight tonne kilometres performed from 2006 to 2016. Revenue passenger kilometres (RPKs) are the total number of passengers carried onboard an aircraft multiplied by the stage length of the flight. ${ }^{83}$ Available freight tonne kilometres (AFTKs) are the mass of air cargo that can be carried onboard an aircraft multiplied by the distance that the air cargo is carried. ${ }^{84}$



Figure 2 Thai Airways International total annual revenue passenger kilometres performed (RPKs) and freight tonne kilometers performed (FTKs): 2006-2016.

Source: Data derived from Thai Airways International. ${ }^{85-89}$

\section{Thai Airways International Airbus A380-800 fleet and cabin configuration}

On the $28^{\text {th }}$ July 2004, the Thai International Airways Board of Directors approved the airline's 2005/2006 to 2009/2010 fleet expansion, which included six long-range, ultra-large aircraft. Thai had been evaluating the Airbus A380 for some time ${ }^{90}$ and the airline planned to operate the aircraft primarily to points in Europe, such as Frankfurt, London and Paris. ${ }^{91}$ The six Airbus A380-800 aircraft were subsequently ordered in $2004^{92}$ and were scheduled to be delivered in late $2008^{91,93}$ and continue through 2009. ${ }^{94}$ In February 2007, Airbus concluded an agreement with Thai to delay the delivery of the A380 aircraft to around September 2010. The airline concluded a further agreement to delay the delivery of its A380 fleet by around four months in February 2009. ${ }^{95}$ In July 2009, Thai and Airbus held further discussions regarding a further delay in the delivery of the A380 until 2012. ${ }^{96,97}$ In mid-March 2010, Thai Airways International unveiled its new fleet renewal strategy, announcing plans to induct 90 aircraft, including the six Airbus A380 aircraft, and retire 77 aircraft over the period 2010 to $2025 .{ }^{98}$ On September 29, 2012, Thai Airways International took delivery of its first Airbus A380 aircraft, ${ }^{99}$ at the time of the present study, Thai had a fleet of 6 Airbus A380800 aircraft. ${ }^{100}$ There are many cabin configurations available for the modern-large widebody aircraft. ${ }^{58}$ The Asian-based airlines typically have a three-class cabin layout. ${ }^{101}$ Thai have followed this trend and their fleet of six Airbus A380-800 are configured in with 12 Royal First Class, 60 Royal Silk Class (business class) and 435 economy class seats, for a total seating capacity of $507 .{ }^{100}$

\section{Deployment of the airbus $\mathbf{A} 380-800$ on Thailand to Europe and return services}

Effective 15 December 2012, Thai commenced daily non-stop Airbus A380 services between Bangkok and Frankfurt and return. ${ }^{4}$ During the 2017/2018 winter flight schedule period, Thai have continued to schedule an A380-800 on the airline's daily TG920/921 services from Bangkok to Frankfurt and return. The aircraft cabin configuration comprises 12 Royal First Class, 60 Royal Silk Class (business class) and 435 economy class seats. The flight is targeted at both premium (first and business class customers) as well as leisure travelers. The total ASKs generated by these Airbus A380-800 services over the 2017/2018 winter flight schedule period are 1.342 billion (Table 1). The total FTKs for these services is 42.3 million AFTKs (Table 1). The total available tonne kilometres that will be generated on these services over the 2017/2018 winter flight schedule period is 183.2 million ATKs.

Thai commenced Airbus A380-800 services from Bangkok to Paris and return on February 16, 2013. ${ }^{104}$ In the 2017/2018 winter flight schedule period, an Airbus A380-800 aircraft is scheduled to operate a daily non-stop service from Bangkok to Paris. The seating configuration on these services is 12 Royal First Class, 60 Royal Silk Class (business class) and 435 economy class seats. Like the Bangkok to Frankfurt Airbus A380 services, the flights to and from Paris are targeted at both premium (first and business class customers) as well as leisure travelers. The total ASKs generated by these Airbus A380800 services over the 2017/2018 winter flight schedule period are 1.41 billion (Table 2). The total AFTKs for these services is 44.4 million AFTKs (Table 2). The total available tonne kilometres (ATKs) that will be generated on these services over the 2017/2018 winter flight schedule period are 192.4 million ATKs (Table 2).

On July $1^{\text {st }}, 2013$, Thai commenced daily Airbus A380 services from Bangkok to London and return. ${ }^{106}$ The A380-800 used on these services has Thai's common A380-800 cabin configuration of 12 Royal First Class, 60 Royal Silk Class (business class) and 435 economy class seats. As such, these flights are aimed at both the premium (first and business class) and the leisure air travel market 
segments. Table 3 shows that during the 2017/2018 winter flight schedule period these services will generate 1.429 billion RPKs, 45.1 million AFTKs and 195.0 million ATKs. Thai's Bangkok to London flights are the longest services operated by the airline's A380-800 aircraft, and thus, they generate greater volumes of RPKs, AFTKs and ATKs, due to the longer flight stage length.

\section{Deployment of the airbus A380-800 on Thailand to Japan and return services}

Effective December 1, 2013, Thai commenced daily Airbus A380800 services from Bangkok to Osaka's Kansai International Airport. ${ }^{108}$
During the 2017/2018 winter flight schedule period, Thai will continue to operate a daily Airbus A380-800 service from Bangkok to Kansai International Airport and return. Like the cabin configuration on the airline's flights from Bangkok to Europe, the Airbus A380-800 deployed on the Bangkok to Kansai International Airport will also have 12 Royal First Class, 60 Royal Silk Class (business class) and 435 economy class seats. Thus, these services are also targeted at the premium and leisure air travel market segments. Table 4 shows that there will be a total of 620.2 million RPKs, 19.5 million AFTKs, and 84.6 million ATKs produced on these services during the 2017/2018 winter flight schedule period.

Table I Airbus A380-800 deployment on Frankfurt services

\begin{tabular}{lllllc}
\hline Sector (City Pair) & $\begin{array}{l}\text { Flight } \\
\text { frequency }\end{array}$ & $\begin{array}{l}\text { Cabin seating } \\
\text { configuration }\end{array}$ & $\begin{array}{l}\text { Flight distance } \\
(\mathbf{k m s})^{\prime}\end{array}$ & Total ASKs & Total AFTKs $^{2}$ \\
\hline BKK-FRA-BKK & Daily & FI2 C60Y435 & 9,009 & $1,342,863,522$ & $42,378,336$ \\
\hline
\end{tabular}

Legend: BKK, Bangkok; FRA, Frankfurt; F, Royal Silk First Class; C, Royal Silk (Business) class; Y, Economy class.

Source: Flight distance ${ }^{102}$ and cargo payload. ${ }^{103}$

Table 2 Airbus A380-800 deployment on Paris services

\begin{tabular}{|c|c|c|c|c|c|c|}
\hline Sector (City pair) & Flight frequency & $\begin{array}{l}\text { Cabin seating } \\
\text { configuration }\end{array}$ & $\begin{array}{l}\text { Flight distance } \\
(\mathbf{k m s})^{\prime}\end{array}$ & Total ASKs & Total FTKs ${ }^{2}$ & Total ATKs \\
\hline BKK-CDG-BKK & Daily & FI2 C60Y435 & 9,460 & $\mathrm{I}, 4 \mathrm{I} 0,088,580$ & $44,499,840$ & $|92,46|, 808$ \\
\hline
\end{tabular}

Legend: BKK, Bangkok; CDG, Charles de Gaulle Airport (Paris); F, Royal Silk First Class; C, Royal Silk (Business) class;Y, Economy class.

Source: Flight distance ${ }^{105}$ and cargo payload. ${ }^{103}$

Table 3 Airbus A380-800 deployment on London services

\begin{tabular}{|c|c|c|c|c|c|c|}
\hline Sector (City pair) & $\begin{array}{l}\text { Flight } \\
\text { frequency }\end{array}$ & $\begin{array}{l}\text { Cabin seating } \\
\text { configuration }\end{array}$ & Flight distance (kms)' & Total ASKs & Total FTKs ${ }^{2}$ & Total ATKs \\
\hline BKK-LHR-BKK & Daily & FI2 C60Y435 & 9,589 & $1,429,317,162$ & $45,106,656$ & $195,086,287$ \\
\hline
\end{tabular}

Legend: BKK, Bangkok; LHR, London Heathrow Airport; F, Royal Silk First Class; C, Royal Silk (Business) class; Y, Economy class.

Source: Flight distance ${ }^{107}$ and cargo payload. ${ }^{103}$

Table 4 Airbus A380-800 deployment on Kansai international airport services

\begin{tabular}{|c|c|c|c|c|c|c|}
\hline Sector (City pair) & Flight frequency & $\begin{array}{l}\text { Cabin seating } \\
\text { configuration }\end{array}$ & $\begin{array}{l}\text { Flight distance } \\
\text { (kms)' }\end{array}$ & Total ASKs & Total FTKs ${ }^{2}$ & Total ATKs \\
\hline BKK-KIX-BKK & Daily & FI2 C60Y435 & $4,|6|$ & $620,230,338$ & $19,573,344$ & $84,6547,128$ \\
\hline
\end{tabular}

Legend: BKK, Bangkok; KIX, Kansai International Airport (Osaka); F, Royal Silk First Class; C, Royal Silk (Business) class; Y, Economy class.

Source: Flight distance ${ }^{109}$ and cargo payload. ${ }^{103}$

Regional distribution of the Thai airways international airbus A380-800 available seat kilometres 2017/20I8 winter flight schedule period

Figure 3 presents the total available seat kilometres (ASKs) that will be produced by the Thai Airbus A380 services during the 2017/2018 winter schedule period. Due to the longer stage length, the most ASKs will be produced by the A380-800 services to London and Paris. The air route from Bangkok to Frankfurt is slightly shorter than that to London and Paris, and thus, the total available seat kilometres are slightly less. As can be seen in Figure 3, the total ASKs produced on Thai's Airbus A380-800 services from Bangkok to Osaka's Kansai International Airport are around half of these of the services to Europe. This reflects the shorter stage length of the service. Figure
4 shows that during the $2017 / 2018$ winter schedule period, 87 per cent of the ASKs produced by Thai Airways International fleet of six Airbus A380-800 aircraft will be generated on the airline's services from Bangkok to Frankfurt, London and Paris, with the remaining 13 per cent being generated on the daily Airbus A380-800 services from Bangkok to Osaka's Kansai International Airport (Figure 4).

Regional distribution of the Thai airways international airbus A380-800 available freight tonne kilometres 20 I $7 / 20$ I 8 winter flight schedule period

Figure 5 shows the total available freight tonne kilometres (AFTKs) that could be produced on Thai's Airbus A380-800 services during the $2017 / 2018$ winter flight schedule period. It is important to note, 
however, that the available air cargo capacity on a flight is influenced by a range of factors including the number of passengers by cabin class, the typical baggage allowance of passengers in each market and by cabin class, flight routings and seasonal payload restrictions. ${ }^{110}$ Thus, the available payload available for air cargo will only be determined on the day of the flight once the airport temperature, flight routing, prevailing headwinds, and other operational considerations have been taken into account, in addition to the flights passenger weight and the number containers used for passenger baggage. ${ }^{44}$ Furthermore, there are significant differences in both passenger and air cargo demand. ${ }^{111}$ Passenger seasonality patterns (for example, Christmas vacation travel peak) are typical and follow year-on-year. ${ }^{112}$ Cargo seasonality patterns, however, are not only heavily influenced by passenger trends but also by other factors that can result in demand patterns to deviate significantly. For instance, the demand for fresh fruit and vegetables depends on crop yields, the prevailing weather at harvest time, and so forth. ${ }^{110}$

Thai Airways Cargo ${ }^{103}$ notes that the approximate air cargo payload available on the airline's Airbus A380-800 services is 16 tonnes. ${ }^{112}$ The total AFTKs shown in Figure 5 were based on this weight estimate. Like the ASKs, the FTKs generated by Thai's Airbus A380-800 aircraft reflect the flight stage length. The largest number of AFTKs will be produced on the Bangkok to London services, followed by the AFTKs produced on the Bangkok to Paris and return services. Due to the slightly shorter flight stage length, the total FTKs of the Bangkok to Frankfurt services are slightly lower than those to London and Paris. Figure 5 also shows that the total AFTKs produced on the daily Airbus A380-800 services between Bangkok and Osaka's Kansai International Airport are slightly less than half of those generated on the airline's services to Europe. Figure 6 shows that during the 2017/2018 winter schedule period, 87 per cent of the AFTKs produced by Thai Airways International fleet of six Airbus A380-800 aircraft will be generated on the airline's services from Bangkok to Frankfurt, London and Paris, with the remaining 13 per cent being generated on the daily Airbus A380-800 services from Bangkok to Osaka's Kansai International Airport. Like the ASKs, this production in AFTKs reflects the longer Airbus A380-800 stage lengths to Europe and the greater number of destinations served by the Airbus A380-800 aircraft.

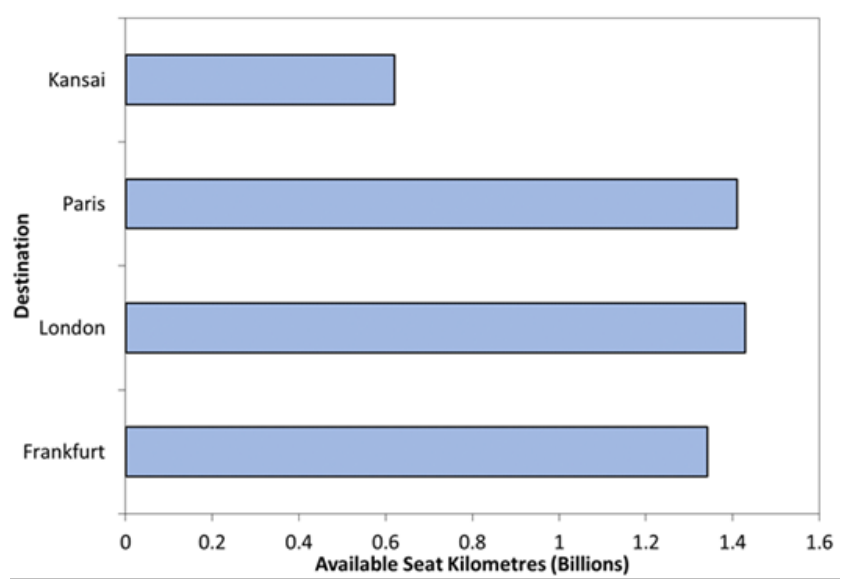

Figure 3 Total available seat kilometres performed (ASKs) on the Thai Airways International Airbus A380 services during the 2017/2018 winter schedule period.

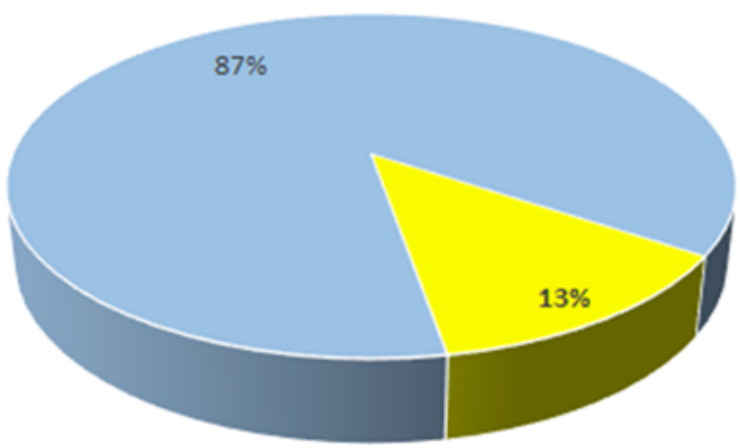

" Europe " Japan

Figure 4 Regional distribution (\%) of the total available seat kilometres (ASKs) produced by Thai Airways International Airbus A380-800 fleet during the $2017 / 2018$ winter flight schedule period.

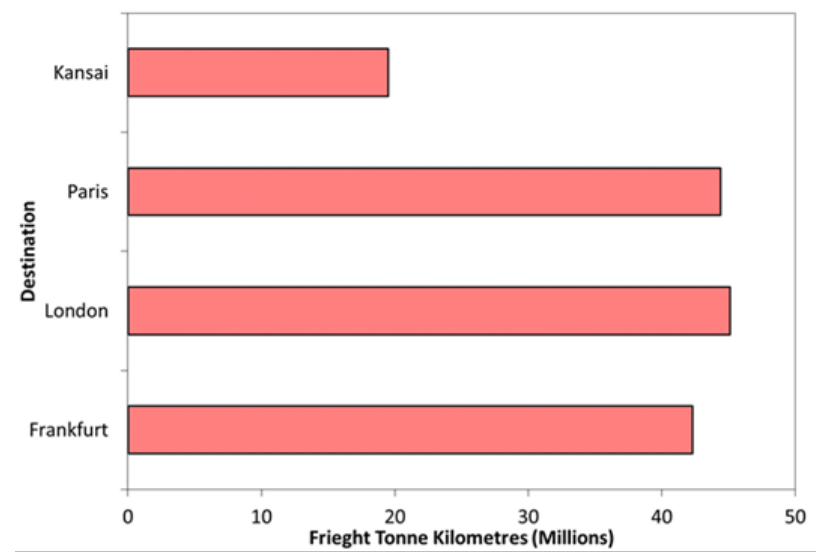

Figure 5 Total available freight tonne kilometres performed (AFTKs) on the Thai Airways International Airbus A380 services during the 2017/2018 winter schedule period

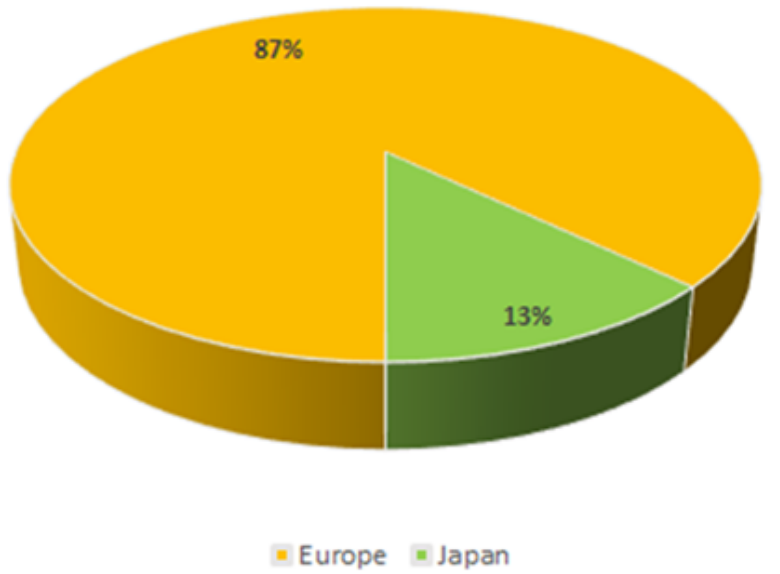

Figure 6 Regional distribution (\%) of the total available freight tonne kilometres (ATKs) produced by Thai Airways International Airbus A380-800 fleet during the 2017/2018 winter flight schedule period. 


\section{Regional distribution of the Thai airways international airbus A380-800 available tonne kilometres 2017/20I8 winter flight schedule period}

As previously noted, the available tonne kilometres are a measure of the tonnes of air cargo, mail and passengers that may be carried on an aircraft times the distance that they are flown. ${ }^{110}$ In order to calculate the total ATKs produced by Thai's Airbus A380-800 services the weight of the cargo ${ }^{112}$ and the weight of the passengers and their baggage ${ }^{23}$ were combined to determine the mass of payload that would be available for transportation on each flight stage length. Once again, Figure 9, shows that Thai's Airbus A380-800 services from Bangkok to London will produce the most ATKs. The services to Paris and Frankfurt will produce 192.4 million and 183.2 million ATKs, respectively (Figure 7). The daily Airbus A380 services serving the Bangkok to Kansai International Airport and return will generate 84.6 million ATKs. However, as noted, the total payload on a flight for the carriage of air cargo is subject to a range of restricting factors, such as temperature restrictions or prevailing winds, which could adversely impact the ability of the aircraft to carry the cargo that is tendered for transportation. In the event of payload restrictions, then the available tonne kilometres will also be affected due to the lower weight of payload being carried on that service. Figure 8 once again shows that 87 per cent of the available tonne kilometres (ATKs) performed by Thai's Airbus A380-800 fleet will be on the European services. The Kansai International Airport services will produce 13 per cent of the available ATKs (Figure 8).

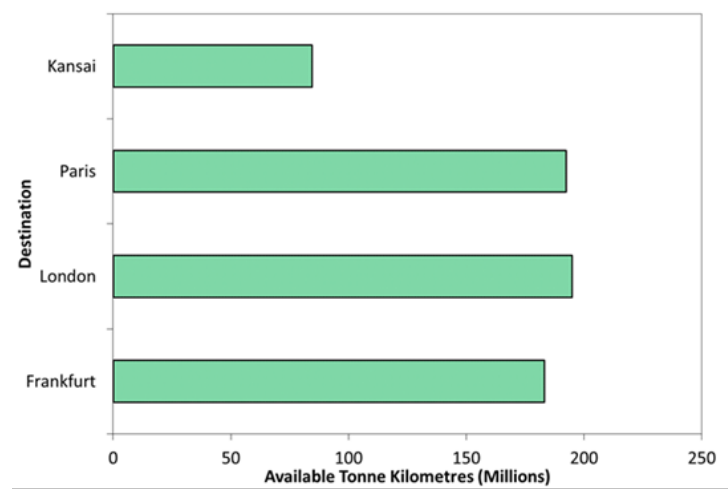

Figure 7 Total available tonne kilometres performed (ATKs) on the Thai Airways International Airbus A380 services during the 2017/2018 winter schedule period.

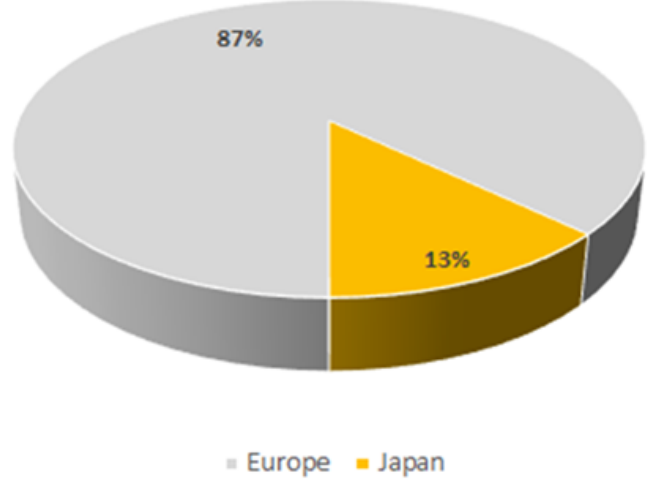

Figure 8 Regional distribution (\%) of the total available tonne kilometres (ATKs) produced by Thai Airways International Airbus A380-800 fleet during the $2017 / 2018$ winter flight schedule period.

\section{Thai international airways airbus $\mathrm{A} 380-800$ route network design}

The Thai Airbus A380-800 route network design is shown in Figure 9. A key element of Thai International Airways business model is its hub-and-spoke route network system. As such, the airline transports both passenger and air cargo traffic from its spoke or peripheral cities to its major hub at Bangkok's Suvarnabhumi Airport at which both passengers and air cargo can connect to their final destinations. The Airbus A380-800 services to Europe are timed to depart from Bangkok in the late evening or very early morning, for example, TG920, the Airbus A380-800 service to Frankfurt departs from Bangkok at 2340hrs, whilst the TG930 and the TG910 Airbus A380 service to Paris and London depart at 0005 and $0010 \mathrm{hrs}$, respectively. Consequently, these departure times enable Thai to carry passenger and air cargo traffic from Australasia, China, Hong Kong, Indonesia, Japan, Korea, and Taiwan to their hub for onward connection to Europe (Figure 10). A comparable situation applies in the reverse direction whereby passenger and air cargo traffic originating in Europe can connect at Suvarnabhumi Airport for onward connection to Australasia, China, Hong Kong, Indonesia, Japan, Korea, and Taiwan. European, Australasian and South-East origin services are timed to arrive at Bangkok and allow sufficient time for passengers and air cargo to connect onto the Airbus A380-800 services from Bangkok to Kansai International Airport.

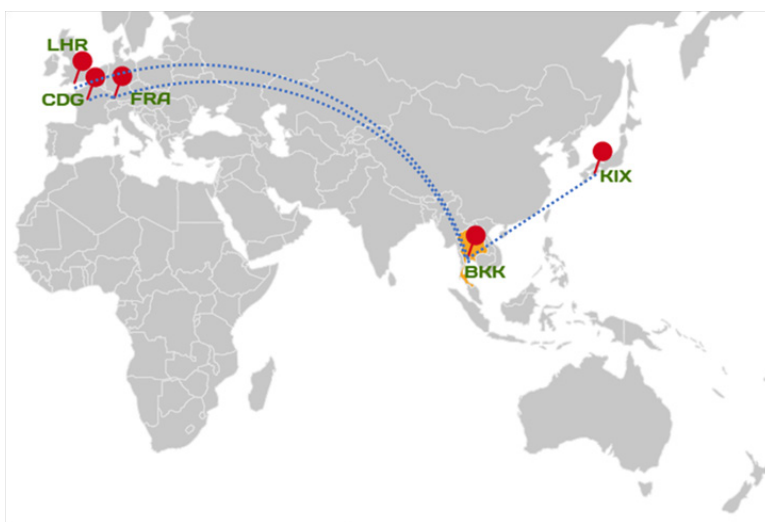

Figure 9 Thai Airways International Airbus A380-800 route network design. Legend: BKK, Bangkok; CDG, Charles de Gaulle Airport (Paris); FRA,

Frankfurt; KIX, Kansai International Airport; LHR, London Heathrow Airport.

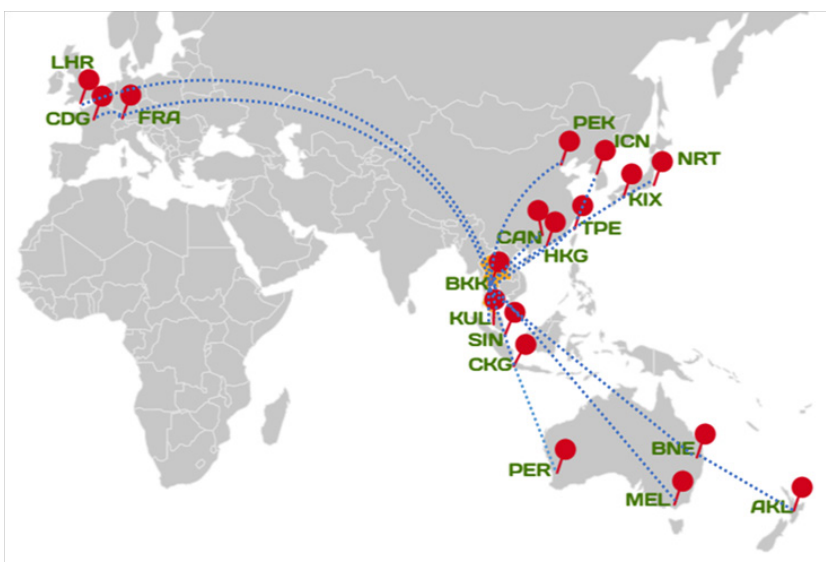

Figure 10 Thai Airways International hub-and-spoke route network design. Legend: BKK, Bangkok; CDG, Charles de Gaulle Airport (Paris); FRA, Frankfurt; KIX, Kansai International Airport; LHR, London Heathrow Airport. 
A comparison of the Thai airways international visà-vis competitor airbus $\mathbf{A} 380-800$ aircraft cabin configurations

As noted earlier, individual space in the aircraft appears to be the key comfort variable for passengers, but so too is the quality of the seating provided by the airline. Comfort is regarded as very important for passengers flying on long-haul intercontinental services, as well as for those flying on business and those travelling on leisure/holiday trips. ${ }^{17}$ There are many cabin configurations available for the modernlarge widebody aircraft, ${ }^{58}$ and thus, an airline will carefully consider their cabin configuration, so as to meet their premium and leisure passengers' expectations. Thai Airways International competes against other Asia/Pacific, Middle East and European-based airlines in the global air travel market. Table 5 shows the Airbus A380800 seating configurations of Thai Airways International Airbus A380-800 as compared to their competitor Airbus A380-800 cabin configurations. As can be seen in Table 5, some airlines operate their aircraft with different cabin configurations, for example, Emirates has a 3 (First, business, economy) class and a high density 2 (business, economy) class Airbus A380 cabin configurations. Singapore Airlines has a strategy, with some Airbus A380 configured in a 4 class (First, business, premium economy, economy) layout and others in a 3 class (first, business, economy) layout (Table 5).

Table 5 Airbus A380-800 operator cabin configurations

\begin{tabular}{lllllr}
\hline Airline & First class & Business class & Premium economy & Economy class & Total \\
\hline Emirates (I) & 14 & 76 & 0 & 427 & 517 \\
Emirates (2) & 0 & 58 & 0 & 557 & 293 \\
Korean & 12 & 94 & 0 & 375 \\
Lufthansa & 8 & 78 & 52 & 399 & 520 \\
Malaysian & 8 & 66 & 0 & 343 & 494 \\
Singapore Airlines (I) & 6 & 76 & 44 & 369 \\
Singapore Airlines (2) & 12 & 86 & 36 & 245 & 379 \\
Thai Airways International & 12 & 60 & 0 & 435 \\
\hline
\end{tabular}

Source:Adapted from Emirates Airline; ${ }^{113}$ Korean Air; ${ }^{114}$ Lufthansa; ${ }^{115}$ Singapore Airlines; ${ }^{116,117}$ Thai Airways International. ${ }^{100}$

A number of airlines around the world have introduced premium economy cabins on their long-haul routes. ${ }^{17,25}$ Based on the concerns of many airline customers that there is a clearly defined requirement for a product that falls between an airline's economy and business class in long-haul markets, ${ }^{92}$ Virgin Atlantic was the first airline to introduce a premium economy product in the mid-1990s for passengers willing to pay the higher end economy fares. ${ }^{92,118}$ The objective of the premium economy cabin class is to provide passengers paying the full economy air fare with a dedicated and quieter aircraft cabin with several inches more leg-room than the normal economy class and better in-flight catering than that offered in economy class. ${ }^{17}$ This product has proved to be quite popular with those high-end leisure travelers and business travelers paying for their airfare themselves. The use of the premium economy product is also considered favorable during economic downturns when business people often do not want to pay the higher business class airfares. ${ }^{92}$ Table 5 shows that both Lufthansa and Singapore Airlines have chosen to offer a premium economy class cabin on their Airbus A380-800 aircraft. At the time of the present study, Thai Airways International had not introduced a premium economy class cabin on their fleet of six Airbus A380-800 aircraft.

As previously noted, airlines all around the world segment their markets into premium and leisure. Table 5 shows that Thai and it competitors are placing a high focus on the premium market segment, offering first class seats and business class lie-flat seats. The number of first and business class seats offered on the Airbus A380-800 varies by carrier (Table 5) with some airlines as few as 6 first class suites (Singapore Airlines) through to 14 first class seats offered on Emirates Airline. Thai offers 12 first class suites on its Airbus A380-800. The number of seats, and space, allocated for business class passengers also varies between operators (Table 5 ). Thai offers 60 business class seats on its fleet of A380-800 aircraft, whilst Korean Air, ${ }^{114}$ Singapore Airlines, ${ }^{116}$ Lufthansa ${ }^{115}$ and Emirates ${ }^{113}$ offer more business class seats in their A380-800 cabin configurations. Nonetheless, the number of first class suites and business class seats shows that the premium air travel market is viewed as highly important by all carriers. This is because such passengers offer high yields to airlines..$^{17,25,28}$

\section{Thai airways international airbus A380-800 fleet deployment strategy}

Airlines acquire aircraft to pioneer new routes or alternatively to replace older, less efficient aircraft. Thai Airways International has not used their Airbus A380-800 to pioneer new routes but rather to replace older aircraft in the airline's fleet. In the 2013/2014 winter flight schedule TG910/911 was operated with a Boeing B747-400 aircraft. This aircraft has now been replaced by the Airbus A380-800 aircraft. A comparable situation applied with the Paris and Frankfurt services, which prior to the arrival of the Airbus A380-800, were predominantly operated by Boeing B747-400 aircraft. The Airbus A380-800 has enabled Thai to withdraw the older, less efficient Boeing B747-400 aircraft from these markets. The introduction of the Airbus A380-800 aircraft has enabled Thai Airways International to enhance its in-flight product. The first and business class cabin layout provides maximum privacy for these premium passengers. The airline has also split Economy class between the main deck and upper deck. All 507 seats on the aircraft have a seat pitch of at least 32 in and all passenger have access to on-board Wi-Fi (for a fee) and to an 'AVOD eX2' personal-touch screen in-flight entertainment system. This system offers passengers a choice of 100 well-chosen film titles, 150 television programs, $500 \mathrm{CD}$ albums as well as 60 games. Thai's primary market is tourism, and thus, the Airbus A380- 
800 aircraft are deployed on dense air routes, where tourism account for a very significant percentage of the passenger traffic. At the same time, Thai is also competing in the premium markets by offering both first and business class products. As noted earlier, the primary markets for Airbus A380 services are from Bangkok to Frankfurt, Kansai International Airport (Osaka), London and Paris.

\section{Thai airways international airbus $\mathrm{A} 380-800$ fleet utilization}

Aircraft utilization is a critical performance indicator for airline operations and is quite often a significant differentiator for some airline business models. ${ }^{119}$ It is important to note that aircraft utilization is a measure of productivity ${ }^{1}$ and is also an important indicator of an airline's operational efficiency. ${ }^{120}$ Aircraft utilization is a function of a variety of elements. These include the aircraft design features and characteristics, airline maintenance programs, airplane technical reliability of the aircraft, airline business philosophy, market demand characteristics, and the availability of trained labor force. Other factors influencing aircraft utilization are the characteristics of the airline's route network, its flight schedule, and the efficiency of the aircraft turnaround process between the inbound flight and the aircraft's next departure ${ }^{16}$ Importantly, improved aircraft utilization helps the airline to spread its fixed ownership costs over a greater number of trips, thereby reducing the costs per seat-mile/per seat kilometre or per trip. ${ }^{119}$ According to Belobaba, ${ }^{16}$ "aircraft utilization is measured in block hours/day per aircraft". Aircraft block hours are the number of hours that are incurred by an aircraft from the moment that it moves under its own power with the intention of operating a flight and until it comes to rest when it blocks at the gate at its destination. ${ }^{121}$ In theory, aircraft utilization is also influenced by the average flight stage length. The operation of longer flights means that the aircraft spends less time on the ground during the day and the turnaround times for an aircraft operating longer haul services, although typically longer than the turnaround times for shorter haul services, does not proportionally increase with stage length. Accordingly, airlines operating longer stage lengths to consistently report higher aircraft utilization rates. ${ }^{16}$

\section{Conclusion}

The objective of this study was to examine the Airbus A380-800 aircraft fleet deployment in the 2017/2018 winter schedule period by Thai Airways International. The period of the study was the winter flight schedule period, which commences on October 29, 2017 and concludes on March 24, 2018. At the time of the study, Thai Airways International had a fleet of six Airbus A380-800 aircraft. These aircraft are predominantly deployed on daily long-haul services from Bangkok to Frankfurt, London and Paris and return. ${ }^{122,123}$ The Airbus A380-800 is also on shorter stage length from Bangkok to Osaka's Kansai International Airport. In deploying these aircraft, Thai is principally competing in two key market segments, the premium (first and business class) and the leisure air travel markets. These markets are "dense", in that they have large annual volumes of travelers. The introduction of the Airbus A380 into the airline's fleet enabled Thai to replace older aircraft types whilst at the same time enhance its inflight product. The Airbus A380 services from Bangkok to London will produce the greatest number of ASKs (1.42 billion), AFTKs (45.1 million) and ATKs (195.0 million). This is followed by Paris with 1.41 billion ASKs, 44.4 million AFTKs and 192.4 million ATKs. Frankfurt

\footnotetext{
${ }^{1}$ Aircraft utilization is the most commonly used metric in evaluating aircraft
} productivity. ${ }^{16}$ is the third largest market with 1.34 billion ASKs, 42.3 million FTKs and 183.2 million ATKs. The daily Airbus A380-800 services between Bangkok and Kansai International during the 2017/2018 winter flight schedule period will produce 620.2 million ASKs, 19.5 million AFTKs and 84.6 million ATKs. The European services generate 87 per cent of the Airbus A380-800 fleet's available seat kilometres (ASKs), available freight tonne kilometres (AFTKs) and available tonne kilometres (ATKs).

\section{Acknowledgements}

None.

\section{Conflict of interest}

The author declares that there is no conflict of interest.

\section{References}

1. Aviation benefits beyond borders. Geneva: Air Transport Action Group; 2016.

2. Dempsey PS, Gesell LE. Air transportation: foundations for the 21st century. Chandler, AZ: Coast Aire Publications; 1997a.

3. Presentation of 2016 air transport statistical results. Canada: International Civil Aviation Organization; 2017. 13 p.

4. UNWTO tourism highlights. Spain: United Nations World Tourism Organization; 2017. 16 p.

5. Hudson S, Hudson L. Marketing for tourism, hospitality \& events: A global \& digital approach. London: SAGE Publications; 2017.

6. Pratoomchat P. Tourism-led growth hypothesis and foreign direct investment in ASEAN. In Ordóńez de Pablos P, Myo AZ (Eds.), Tourism and opportunities for economic development in Asia. Hershey, PA: IGI Global; 2017. 203-223 p.

7. Scilla A, Viassone M. Innovation and sustainability: the road to success for wine tourism destinations. In Vrontis D, Bresciani S \& Rossi M (Eds.), Managing globalization: new business models, strategies and innovation. Newcastle-upon-Tyne: Cambridge Scholars Publishing; 2016. 249-275 p.

8. Mason K, Morrison WG, Stockman I. Liberalization of air transport in Europe and the evolution of 'low-cost' airlines. In Forsyth P, Gillen D, Huschelrath K, Niemeier HM \& Wolf H (Eds.), Liberalization in aviation: competition, cooperation and public policy. Abingdon, UK: Routledge; 2016. 141-155 p.

9. Taneja NK. Airline industry: poised for disruptive innovation? Abingdon, UK: Routledge; 2017.

10. Whyte R, Lohmann G. Airline business models. In Budd L \& Ison S (Eds.), Air transport management: An international perspective. Abingdon, UK: Routledge; 2017. 107-121 p.

11. Koch B. Aviation strategy and business models. In Wald A, Fay C \& Gleich $\mathrm{R}$ (Eds.), Introduction to aviation management. Münster, Germany: LIT Verlag; 2010. 154-170 p.

12. Baxter GS, Bardell NS. Can the renewed interest in ultra-long-range passenger flights be satisfied by the current generation of civil aircraft? Aviation. 2017;21(2):42-54.

13. Gillen D. Aviation economics and forecasting. In Budd L \& Ison S (Eds.), Air transport management: An international perspective. Abingdon, UK: Routledge; 2017. 23-40 p.

14. Gross S, Klemmer L. Introduction to tourism transport. Wallingford, UK: CABI Publishing; 2014. 
15. O’Connell JF, Williams G. Glossary: definitions of commonly used air transport terms. In O'Connell JF \& Williams G (Eds.), Air transport in the 21st century: key strategic developments. Abingdon, UK: Routledge; 2016.

16. Belobaba PP. Airline operating costs and measures of productivity. 2nd ed In Belobaba P, Odoni A \& Barnhart C (Eds.). The global airline industry. Chichester, UK: John Wiley \& Sons; 2016a. 127-158 p.

17. Doganis R. Flying off course: The economics of international airlines. 4th ed. Abingdon, UK: Routledge; 2010.

18. Holloway S. Straight and level: practical airline economics. 3rd ed. Abingdon, UK: Routledge; 2016.

19. Bureau of Transport and Communication Economics. International aviation trends and issues. Report 86. Canberra: Australian Government Publishing Service; 1994.

20. Vogel G. Flying the Airbus A380. Marlborough, UK: Airlife Publishing; 2009.

21. Eden PE. The world's greatest civil aircraft: An illustrated history. London, UK: Amber Books; 2015.

22. Simons GM. The Airbus A380: a history. Barnsley, UK: Pen \& Sword Aviation; 2014.

23. The month in review: June 2018. France: Airbus SAS; 2018.

24. Ehmer H, Berster P, Bischoff G, et al. 2008. Analyses of the European air transport market-airline business models. Germany: DLR Air Transport and Airport Research; 2008. 44 p.

25. Clark P. Buying the big jets: fleet planning for airlines. 3rd ed. Abingdon, UK: Routledge; 2017.

26. Belobaba PP. The airline planning process. In Belobaba P, Odoni A Barnhart C (Eds.). The global airline industry (2nd ed.) Chichester, UK John Wiley \& Sons; 2016b. 159-188 p.

27. Baxter GS. AERO2410 Airline operations: topic 6 learning guide airline capacity management and passenger aircraft fleet planning. Melbourne, Australia: RMIT University; 2016.

28. Wensveen JG. Air transportation: a management perspective. 8th ed. Abingdon, UK: Routledge; 2016.

29. Holloway S. Straight and level: practical airline economics. Aldershot, UK: Ashgate Publishing; 1997.

30. Bazargan M. Airline operations and scheduling. Abingdon, UK: Routledge; 2016. 302 p.

31. Nadadur G, Parkinson MB. Using designing for human variability to optimize aircraft seat layout. SAE International Journal of Passenger Cars-Mechanical Systems. 2009;2(1):1641-1648.

32. Kundo AK. Aircraft design. New York: Cambridge University Press; 2010

33. Bowen JT. The economic geography of air transportation: space, time, and the freedom of the sky. Abingdon, UK: Routledge; 2010. 352 p.

34. Mancini M. Access: introduction to travel and tourism. Clifton Park, NY: Cengage Learning; 2013.

35. Dempsey PS, Gesell LE. Airline management: strategies for the $21^{\text {st }}$ century. Chandler, AZ: Coast Aire Publications; $1997 \mathrm{~b}$.

36. Reynolds-Feighan AJ. The E.U. and U.S. air freight markets: network organization in a deregulated environment. Transport Reviews. 1994;14(3):193-217.

37. Button KJ, Haynes K, Stough R. Flying into the future: air transport policy in the European Union. Cheltenham, UK: Edward Elgar Publishing; 1998. $199 \mathrm{p}$.
38. Morrison SA. Airline service: The evolution of competition since deregulation. In Tremblay VJ, Tremblay $\mathrm{CH}$ (Eds.). Industry and firm studies (4th ed.) Abingdon, UK: Routledge; 2015. 3-29 p.

39. Forsyth P, Papatheodorou A, Graham A. Conclusions: Themes and future issues. In Graham A, Paatheodorou A \& Forsyth P (Eds.), Aviation and tourism: implications for leisure travel. Abingdon, UK: Routledge; 2016. 335-345 p.

40. Shaw S. Airline marketing and management. 7th ed. Abingdon, UK: Routledge; 2011.

41. Ashford NJ, Mumayiz SA, Wright PH. Airport engineering: Planning, design, and development of 21st century airports. 4th ed. Hoboken: John Wiley \& Sons; 2011. 753 p.

42. Cook GN, Billig BG. Airline operations and management: a management textbook. Abingdon, UK: Routledge; 2017.

43. World air cargo forecast 2016-2017. USA: Boeing Commercial Airplanes; 2016. $72 \mathrm{p}$.

44. Morrell PS. Moving boxes by air: the economics of international air cargo. Abingdon, UK: Routledge; 2016.

45. Tretheway MW, Andriulaitis RJ. Airport competition for freight. In Forsyth P, Gillen D, Müller J \& Niemeier HM (Eds.), Airport competition: the European experience. Abingdon, UK: Routledge; 2016. 137-148 p.

46. Superjumbo origins. Flight International. 2005;167(4989):53.

47. Kingsley Jones M. Lean and green. Flight International. 2009a;175(5170):30-32.

48. Kingsley Jones M. All change. Flight International; 2005. 12-13 p.

49. Long-haul evolution: A380 or sonic cruiser? Aircraft Commerce. 2002;25:11-17.

50. Pilling M. Cruise speed. Flight International; 2005a. 4-6 p.

51. Long AC. Introduction. In AC Long (Ed.). Design and manufacture of textile composites. Cambridge, UK: Woodhead Publishing; 2005.

52. Kingsley Jones M. Judging a giant. Flight International. 2009b;176(5214):66-73.

53. Reckzeh D. Aerodynamic design of the high-lift-wing for a Megaliner aircraft. Aerospace Science and Technology. 2003;7(2):107-119.

54. Kingsley Jones M. Ultra effort. Flight International. 2007a:172(5109):28-34.

55. Ionides N. Ready at last. Flight International. 2007;172(5109):38-40

56. Kingsley Jones M. Making it big. Flight International. 2007b;172(5110):41.

57. Kingsley Jones M. Failure never an option. Flight International. 2008;173(5123):32-33.

58. Fuel burn \& operating performance of the A380, 777-300ER \& 747-400. Aircraft Commerce. 2015;99:25-32.

59. Dawes Farquhar J. Case study research for business. London, UK: SAGE Publications; 2012.

60. Yin RK. Case study research: design and methods. $6^{\text {th }}$ ed. Thousand Oaks, CA: SAGE Publications; 2017.

61. Chambliss DF, Schutt RK. Making sense of the social world: methods of investigation. $4^{\text {th }}$ ed. Thousand Oaks, CA: SAGE Publications; 2013. $400 \mathrm{p}$.

62. Morse JM, Niehaus L. Mixed method design: principles and procedures. Abingdon, UK: Routledge; 2016.

63. Yin RK. Case study research: design and methods. $4^{\text {th }}$ ed. Thousand Oaks, CA: SAGE Publications; 2009. 
64. Oates BJ. Researching information systems and computing. London, UK: SAGE Publications; 2006.

65. McNabb DE. Research methods in public administration and nonprofit management: quantitative and qualitative approaches. 3rd ed. Abingdon, UK: Routledge; 2013

66. Ramon Gil-Garcia J. Enacting electronic government success: an integrative study of government-wide websites, organizational capabilities, and institutions. New York: Springer Science-Business Media; 2012.

67. Andrew DPS, Pedersen PM, McEvoy CD. Research methods and design in sport management. Champaign, IL: Human Kinetics; 2011. 304 p.

68. Scott JA. Dictionary of sociology. 4th ed. Oxford, UK: Oxford University Press; 2014

69. Scott J, Marshall GA. Dictionary of Sociology. 3rd ed. Oxford, UK Oxford University Press; 2009.

70. Love P. Document analysis. In Stage FK, Manning K (Eds.). Research in the college context: approaches and methods. New York: BrunnerRoutledge; 2003. 83-96 p.

71. Chester L. A regulationist analysis of an industry sector using mixed research methods. In Lee FS, Cronin B (Eds.). Handbook of research methods and applications in heterodox economics. Cheltenham, UK: Edward Elgar Publishing; 2016. 569-590 p.

72. Kridel C. An introduction to documentary research. Washington: American Educational Research Association; 2018.

73. Wellington J. Educational research: contemporary issues and practical approaches. 2nd ed. London, UK: Bloomsbury Academic; 2015.

74. Scott J. A matter of record: Documentary sources in social research. Cambridge, UK: Polity Press; 1990.

75. Scott J. Documents, types of. In Lewis-Beck MS, Bryman AE, Futing Liao $\mathrm{T}$ (Eds). The SAGE encyclopaedia of social science research methods. Thousand Oaks, CA: SAGE Publications; 2004. 281-284 p.

76. Olson M. Document analysis. In Mills AJ, Durepos G, Wiebe E (Eds.) Encyclopaedia of case study research. Thousand Oaks, CA: SAGE Publications; 2010. 318-320 p.

77. O'Leary Z. The essential guide to doing research. London, UK: SAGE Publications; 2004.

78. Green W, Swanborough G. The observer's world: airlines and airliners directory. London, UK: Frederick Warne \& Co. Ltd; 1975.

79. SAS-Thai agreement. Aviation Week. 1959;71(9):49.

80. Brimson S. The airlines of the world. Sydney, Australia: Dreamweaver Books; 1985.

81. Wright AJ. Airline fleet list. London, UK: Ian Allan Ltd; 1986.

82. Company profile. Thai Airways International; 2018b.

83. Beaver AA. Dictionary of travel and tourism terminology. Wallingford, UK: CABI Publishing; 2005. 400 p.

84. Daley B. Air transport and the environment. Abingdon, UK: Routledge; 2016.

85. Annual report 2006. Bangkok: Thai Airways International Public Company Ltd; 2006. 172 p.

86. Annual report 2010. Thai Airways International Public Company Ltd; 2010. 184 p.

87. Annual report 2012. Bangkok: Thai Airways International Public Company Ltd; 2012. 208 p.
88. Annual report 2014. Bangkok: Thai Airways International Public Company Ltd; 2014. 216 p.

89. Annual report 2016. Bangkok: Thai Airways International Public Company Ltd; 2016. 216 p.

90. Ionides N. Thai includes A380s in fleet expansion plan. Flight International, 2004;166(4945):4.

91. Pilling M. Feeding time. Airline Business; 2005b. 20-22 p.

92. Taneja NK. Fasten your seatbelt: the passenger is flying the plane. Abingdon, UK: Routledge; 2016.

93. Pilling M, Doyle A, Ionides $\mathrm{N}$, et al. Space race. Flight International; 2005. 28-31 p.

94. Ionides N. Thai steps up A350 and 787 evaluations. Flight International. 2006;170(5048):16.

95. Francis L. Thai Airways in talks to delay A380 again. Flight International. 2009; 175(5173):10

96. Dunn G. Turning the tide at Thai Airways. Airline Business. 2009;25(12):16.

97. Thai in talks to delay A380 deliveries to 2012. Flight International. 2009;176(5198):11.

98. Thai fleshes out fleet revamp plans. Flight International. 2010;26(4):16

99. Thai Airways Receives First A380 Superjumbo. New York: Bloomberg; 2012.

100. Aircraft: Airbus A380-800. Thai Airways International; 2018a.

101. Kaminski Morrow D. Class war as BA pushes up premiums. Flight International. 2012;182(5371):13.

102. BKK-FRA map. Great Circle Mapper; 2018 b.

103. Our fleet. Bangkok: Thai Cargo; 2018.

104. Flynn D. Thai's Airbus A380 routes: HK, Singapore, Frankfurt, Tokyo, Osaka, Paris, Sydney \& London. Australian Business Traveller; 2012.

105. BKK-CDG map. Great Circle Mapper; 2018a.

106. Chamberlin C. Thai Airways upgrades London to A380, halves Heathrow flights. Australian Business travel; 2015.

107. BKK-LHR map. Great Circle Mapper; $2018 \mathrm{~d}$.

108. THAI to start Airbus A380 service to Osaka from late-October 2013. UK: Routes Online; 2013.

109. BKK-KIX map. Great Circle Mapper; $2018 \mathrm{c}$.

110. Billings JS, Diener AG, Yuen BB. Cargo revenue optimization. Journal of Revenue and Pricing Management. 2003;2(1):69-79.

111. Otto A. Reflecting the prospects of an air cargo carrier. In Delfmann W, Baum H, Auerbach S \& Albers S (Eds.), Strategic management in the aviation industry. Abingdon, UK: Routledge; 2017. 452-471 p.

112. Vasigh B, Tacker T, Fleming K. Introduction to air transport economics: From theory to applications. Abingdon, UK: Routledge; 2016.

113. Seating chart. Dubai: Emirates Airline; 2018

114. Airbus 380-800(399). Korean Air; 2018

115. Airbus A380-800 seat map. Lufthansa German Airlines; 2018.

116. Airbus A380-800. Singapore Airlines; 2018a.

117. Airbus A380-800. Singapore Airlines; 2018b. 
118. Doganis R. The airline business. Abingdon, UK: Routledge; 2006.

119. Mirza M. Economic impact of airplane turn-times. Geneva: AERO Magazine Quarter 4; 2008. 6 p.

120. Vasigh B, Taleghani R, Jenkins D. Aircraft finance: strategies for managing capital costs in a turbulent industry. Fort Lauderdale: J. Ross Publishing; 2012.
121. Cannon JR, Richey FD. Practical applications in business aviation management. Lanham, MD: Government Institutes; 2012. 384 p.

122. Airbus family figures. France: Airbus SAS; 2017. 32 p.

123. Rahim AR, Baksh MS. Case study method for new product development in engineer-to-order organisations. Work Study. 2003;52(1):25-36. 